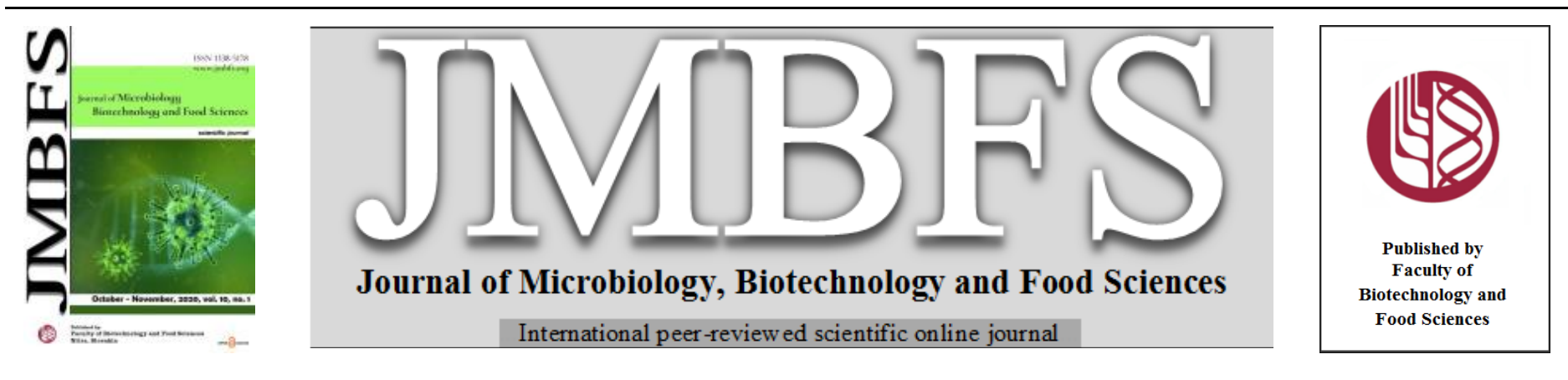

\title{
FORMATION AND FUNCTIONING OF CHAETOMIUM COCHLIODES / FAGOPYRUM ESCULENTUM ENDOPHYTIC ASSOCIATION
}

\author{
Evheny Kopilov, Anna Kyslynska*, Olena Nadkernychna, Hanna Tsekhmister
}

Address(es): Anna Kyslynska, PhD,

The Laboratory of Plant-Microbial Interactions, The Institute of Agricultural Microbiology and Agroindustrial Manufacture, The Ukrainian National Academy of Agrarian Sciences, 97, Shevchenko Str., Chernihiv City, 14035, Ukraine.

*Corresponding author: a.s.kyslynska@gmail.com

doi: 10.15414/jmbfs.2020.10.2.190-196

\section{ARTICLE INFO}

Received 9. 8. 2019

Revised 8. 6. 2020

Accepted 11. 6. 2020

Published 1. 10. 2020

Regular article OPEN $\partial_{\text {AcCESS }}$

\begin{abstract}
Many representatives of soil saprotroph fungi can penetrate into plant tissues forming endophytic associations with a positive effect on both micro- and macroorganisms. The endophytic fungi may positive act on growth processes, immune status, and resistance of plants to stress factors. For some crops, including buckwheat, the ability to form endophytic associations with soil fungi remains unexplored. Thus the main objectives of our study were to establish the features of interaction between Chaetomium cochliodes 3250 and buckwheat plants. Conventional biochemical (content of plant growth regulators, activity of succinate dehydrogenase, acid and alkaline phosphatase, exoglucanase, endoglucanase, $\beta$-glucosidase, polygalacturonase) and physicochemical (content of photosynthetic pigments) study methods were used during the work. We established the capability of $C$. cochliodes 3250 for growth-regulating substances synthesis. The fungus could produce indolyl 3-acetic acid, gibberellic acid, that stimulates growth and development of plants both with mediator molecules, synthesizes 2,4-epibrassinolide, cholesterol and ergosterol playing an important role in plant resistance against pathogens. We found out that $C$. cochliodes 3250 was capable for active synthesis of cellulase complex enzymes (exoglucanase, endoglucanase, $\beta$-glucosidase) and polygalacturonase, necessary for fungus penetration into the root tissues. Pre-sowing treatment of buckwheat seeds by fungus caused the main physiological responses of plants: an increase of total adsorption and active working surface of the roots, the length and weight of plants, the leaf area and the content of chlorophylls $a$ and $b$. Thus, the ability of $C$. cochliodes 3250 to form an efficient endophytic association with buckwheat plants been improved.
\end{abstract}

Keywords: soil fungus Chaetomium cochliodes, buckwheat, endophytic association

\section{INTRODUCTION}

In recent decades, along with the mycorrhizal symbiosis, significant attention of researchers was paid at another scantily studied process, namely endophytism of soil saprotrophic fungi to the plant roots. The metabolic and growth processes activated more than usual ones, the immune status is enhanced and stress resistance is raised up in plants infected with endophytic fungi (Arnold, Harre,2003; Waller et al., 2005; Marquez et al., 2007; Antonyak et al., 2013). In turn, the localization of endophytes in plant tissues protects them from adverse environmental conditions, while they do not compete with rhizosphere microflora and have direct access to nutrients synthesized by plants. The formation of endophytic systems is not a prerequisite for plant development. In addition, fungi can exist for a long time in plant tissues without any signs of their presence and become to evince their activity under adverse environmental conditions: moisture and mineral nutrient deficiencies, the negative effects of environmental factors (Lutova et al., 2000; Spatafora et al., 2007). Acremoniun, Alternaria, Aspergillus, Chaetomium, Cladosporium, Claviceps, Collectotrichum, Cryptococcus, Curvularia, Diaporthe, Epicoccum, Fusarium, Geomyces, Glomus, Leptospora, Microdochium, Neotyphodium, Paecilomyces, Penicillium, Phaeomoniella, Piriformospora, Rhizoctonia, Rhizopus, Rhodotorula, Sarocladium, Talaromyces, Trichoderma, Wallemia and Xylaria are mentioned as endophytes of the crops majority (Charest et al., 1993; Cevnik et al., 2000; Tsavkelova et al., 2005; Subramanian, Charest, 1997; Hause, Fester, 2005; Ding et al., 2005; El-Zayat, 2008; Hata et al., 2010; Kopylov, 2013; Singh, 2017; Rana,Kour et al., 2016; Rana, Yadav et al., 2016, Yadav et al., 2017; Spagnoletti et al., 2016). The search for symbiotically efficient endophytic fungi and establishment of their features according to interaction between plants and soil fungi are still in the focus of intensive studies. Despite the significant amount of fungi capable to form mycorrhizal or endophytic symbiosis, many researchers investigated a large number of plant abilities to form associative systems with micromycetes that had not been established. One of such important crops beingis buckwheat plants.J.L.Harley and E.L.Harley (Harley, Harley, 1987), J.P.Gai et al. (Gai et al.,
2006), B.Wang and Y.L.Qiu (Wang, Qiu, 2006) could not find any signs of buckwheat plantscolonization with mycorrhizal fungi. At the same time, the first results of molecular genetic analysis with fungi isolated from edaposphere and rhizosphere, the sequenced DNA fragments found to be close to Glomusspecies (Likar et al., 2008). Therefore the issue of mycorrhizal endophytic symbiosis formed with buckwheat is controversial and has not been completely established. At the early stages of vegetation, buckwheat plants are particularly susceptible to nitrogen and phosphorus intakes; the lack of these elements in mineral nutrition of plants can cause delay in growth and the root system development. Providing buckwheat with all necessary elements is possible due to mineral fertilizers. Another way for the environment to stay safe is the usage of endophytic fungi in root zone forming plant-microbial associations. Thus it is important and timely to search for endophytic saprotrophic fungi that are able to survive in sowing buckwheat root zone and affect positively for the yield and products quality. Chaetomium is one of the largest genera of the Chaetomiaceae family, which is represented by more than 100 species (Zhang and Soytong, 2013). An active biological control agents were identified among the fungi of this genus; they tread down the growth of bacteria and fungi by direct competition, microparasitism or antibiosis (Sibounnavongetal., 2011). A large number of the Chaetomium metabolism biologically active products are known. Micromycete C. atrobrunneum L. M. Ames produces fungicides fuscoatroside and heteatrosine (Hwangatal., 2000; Kobayashi et al., 2005), C. cochliodes Palliser - antibiotic hetamine (Geigeretal., 1944), C. globosum Kunse - phytotoxinazophilone and hematomohiline D and $\mathrm{J}$, antibiotics Hetamine and Hetirovidine (Piyasena et al., 2015). C. gracile Udagawa is an antimicrobial hetochromin A (Bai et al., 2015).

It is known, that soil saprotrophic fungus Chaetomium cochliodes 3250 introduced into the root zone of spring wheat and soybeans, develops actively on the plants roots and forms fruiting bodies on the surface of roots and root hairs. Moreover, it penetrates into the rhizoderm cells, indicating the formation of endophytic associations. (Kopilov, Nadkernichny, 2008; Kopylov et al., 2010). 
Therefore, the focus of our studying was the interactions between macro- and microsymbionts in endophytic association of Chaetomium cochliodes 3250 /Fagopyrum esculentum.

\section{MATERIALS AND METHODS}

\section{The fungus strain}

Chaetomium cochliodes Palliser 3250 is a fungus strain with antagonistic activity taken from useful soil micro-organisms collection at The Institute of Agricultural Microbiology and Agro-Industrial Production NAAS (Volkogon et al., 2015). The $C$. cochliodes 3250 fruiting bodies are located on the mycelium surface and grow in large numbers. They are round, oval, with their colour ranging from dark green to dark brown, with plant tillers and rhizoids at the bottom. Bags are clubshaped and octosporous. Ascospores are oval and lemon-shaped.

\section{The fungus cultivation for growth regulating substances determination}

C. cochliodes 3250 was cultivated within 18 days at a temperature of $+25-26^{\circ} \mathrm{C}$ in liquid medium (Belyavskaya et al., 2009). The $\mathrm{pH}$ value was 7,0. After the fermentation the fungus titer came to $(3-4) \times 10^{5}$ colony forming units $(\mathrm{CFU})$ in $1 \mathrm{ml}$ of the cell culture fluid.

\section{Growth regulators content determination}

The liquid medium was evaporated to dryness in the vacuum. Then we made triple extraction using methanol/acetonitrile mixture (1:1). The obtained extractions were mixed up and evaporated in the vacuumat at the temperature of $+45^{\circ} \mathrm{C}$.

Auxins and cytokines determination were carried out using method of spectrodensitometric thin-layer chromatography. Phytohormones detection was made via scanning spectrosensometer "Sorbphil" (Russia). The number of synthesized phytohormones was calculated in $\mu \mathrm{g} / \mathrm{ml}$ of fungus liquid medium. The quantitative content of gibberellins and brosinosteroids was made via highpressure efficient chromatography method (liquid chromatography Aligent Technologies 1200 (USA) with mass spectrometric detector Agilen Technologies G1956B (USA). The Zorbax SB-C18 chromatographic column $(2,1$ $\mathrm{mm} \times 150 \mathrm{~mm}, 3 \mu \mathrm{m})$ (Aligent Technologies, USA) beenusedduringresearch (150 $\mathrm{mm}$ length, $4 \mathrm{~mm}$ diameter). The moving phase flowing through the column was $0,35 \mathrm{ml} / \mathrm{min}$, the thermostat column temperature was $30^{\circ} \mathrm{C}$, the volume of injections was $3 \mu$ l.Diode-matrix detector was used for registration at 198 and $210 \mathrm{~nm}$ fixing absorption spectra at 190-400 $\mathrm{nm}$. Fluorescent detector was used with $210 \mathrm{~nm}$ extinction waves and $410 \mathrm{~nm}$ with emissions. Moving phase acetonitrile/water (75:25) Appropriate Sigma solutions (USA) were used as standards for comparison.

\section{The fungus cultivation for cellulosic and polygalacturonase activity determination}

C. cochliodes 3250 was cultivated within 12 days at a temperature of $+25-26{ }^{\circ} \mathrm{C}$ in modified Czapek liquid medium $\left(\mathrm{g} / \mathrm{l}:\left(\mathrm{NH}_{4}\right)_{2} \mathrm{HPO}_{4}-2,5 ; \mathrm{K}_{2} \mathrm{HPO}_{4}-1,0\right.$ $\left.\mathrm{MgSO}_{4}-0,5 ; \mathrm{KCl}-0,5 ; \mathrm{FeSO}_{4}-0,01\right)$. The strip of filter paper $(50 \mathrm{mg})$ was used as the only source of carbon. $\mathrm{pH}$ value was 7,0 . The spore suspension with a caption of $1 \times 10^{6} \mathrm{CFU}$ was used for seeding at the amount of $5 \%$ to the nutrient medium volume. The fungus conidia and hyphae fragments for $C$. cochliodes 3250 seed material was washed off from the wort-agar tubes. After the biomass cultivation it was separated with filtering through the porcelain sieve. The obtained filtrate was used for carrying out the tests.

\section{Cellulosic complex components activity test}

The accounting was made on 3, 6, 9 and 12 days of cultivation. The Czapek medium without fungus was used as a control variant. Exoglucanase, endogluconase and $\beta$-glucosidase were enzymes of the cellulase complex. The unit of exoglucanase activity was the quantity of enzyme capable for forming of $1 \mathrm{mg}$ reducing sugars. The units of endogluconase $\beta$-glucosidase were the quantity of enzymes capable to form the $1 \mathrm{mg}$ reducing sugars for 30 minutes. As a substrate we used avicel in quantity of $50 \mathrm{mg}$ (Sigma, USA), $1 \mathrm{ml} \mathrm{0,5 \%} \mathrm{Na-}$

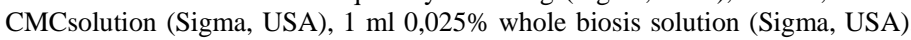
Sodium citrate buffer concentration was $0,05 \mathrm{M}$. The number of reducing sugars was detected with Somogy-Nelson method (Bilay, 1982). The test mixture was being incubated at $40^{\circ} \mathrm{C}$. The standard glucose solutions were used for calibration curve building.

\section{Material plant growing}

The ability of $C$. cochliodes 3250 for forming associative system with buckwheat plants of Antaria sort was tested during vegetative experiment within 40 days using $2 \mathrm{dm}^{3}$ plastic vessels.
The type of soil was sod-medium podzolic sulfur-sandstone; the humus contents $-1,02 \%$; the nitrogen contents $-54,9 \mathrm{mg} / \mathrm{kg}$; the moving forms of phosphorus contents $-110-120 \mathrm{mg}_{2} \mathrm{O}_{5}$; the exchangeable potassium contents - 120-130 mg $\mathrm{K}_{2} \mathrm{O}$ per $1 \mathrm{~kg}$ of soil; $\mathrm{pH}_{\text {salt. }}-5,2 ; \mathrm{pH}_{\text {water }}-6,0 ; \mathrm{Ca}-5,8, \mathrm{Mg}-0,61 \mathrm{mg} \cdot$ eq per $100 \mathrm{~g}$ of soil.

In control variant the seeds were moistened with water (1\% by weight). Presowing treatment of control seeds by $C$. cochliodes 3250 was made in quantity of $4 \times 10^{5} \mathrm{CFU}$ per 1 seed

The seeds were planted to a depths of $2,0 \mathrm{~cm}$. Each vessel contained 15 plants with the future thinning to 10 .

\section{Plant material preparing}

The samples of roots were taken out at 20,30, 40 day. Then the roots were washed with drain and sterile water, chopped and homogenized in $0,1 \mathrm{M}$ phosphate buffer in the ratio of $1: 10$

\section{Succinatedehydrogenase activity determination}

Succinatedehydrogenase activity $(\mathrm{SDH})$ in control variant roots and in oculated plants with $C$. cochliodes 3250 was conducted using potassium ferriyanide (Resyapkin, Slyshkov, 2009). Because of the SDH actions, the succinate recovered potassium ferricyanide $\left(\mathrm{K}_{3}\left[\mathrm{Fe}(\mathrm{CN})_{6}\right]\right)$, the solution of which had at first a yellow color, to a colorless potassium ferrocyanide $\left(\mathrm{K}_{4}\left[\mathrm{Fe}(\mathrm{CN})_{6}\right]\right)$, with enzyme activity proportional to the amount of reduced ferricyanide.

A mixture of $20 \%$ trichloroacetic acid and $0.1 \mathrm{M}$ phosphate buffer in a 1: 1 ratio was used as the optical control.

To determine potassium ferriyanide in tested samples we made a calibration curve (from 100 to $1000 \mu \mathrm{g}$ of ferriyanide in $4 \mathrm{ml}$ of sample solution).

The amount of ferricyanide that was recovered during incubation was calculated due to the difference in existences. As the reaction proceeds stoichiometrically, SDH activity was expressed by the amount of oxidized succinate and measured in nmolsuccinate / $\mathrm{mg}$ protein per $1 \mathrm{~min}$. The 3-times biological and 3-times analytical replicates were used.

\section{Acid and alkaline phosphatase activity}

Acid and alkaline phosphatase activity in control variant roots and buckwheat plants inoculated with $C$. cochliodes 3250 were detected using photocolorimetry method, based on hydrolysis of glycerophosphate with phosphatase solution in the presence of the appropriate buffer (acid phosphatase - $\mathrm{pH} 5,2$, alkaline phosphatase - pH 8,9)(Ermakov et al., 1972). The content of inorganic phosphorus in filtrate was detected by Lowry and Lopez method modified by Skulachev (Ermakov et al., 1972). The method is based on transformation of phosphoric molybdenum acid complex by ascorbic acid. Sensitization of the reaction was achieved by $\mathrm{Cu}^{2+}$ ions in incubative solution. According to the series of potassium dihydrogenphosphate solutions with different concentration calibration curve was built. Phosphatase activity was expressed in milligrams of inorganic phosphorus excretion by enzyme action on $1 \mathrm{~g}$ of tissue.

\section{Physiological characteristics of buckwheat plants studying}

General and working adsorption surface detection was made according to the Sabin and Kolosov method using methylene blue (Gorodniy et al., 2005).

Biometric indexes of plants were detected with measuring-weight method.

The area of photosynthetic surface was detected with the carving method (Tretyakov et al., 1990).

The maintenance of chlorophyll $a$ and $b$ were detected spectrophotometrically (Grodzinsky, 1973).

\section{Statistical analysis}

Calculations and statistical analysis of the obtained results were made according to generally accepted methods. Parametric criteria for normal distribution were used determining arithmetic mean and square deviation mean less than 0,05 significance level. Microsoft Excel were used for processing. To assess the reliability of the differences between variants the slightest significant difference $\left(\mathrm{SSD}_{05}\right)$ was calculated.

\section{RESULTS}

\section{Growth-regulating substances of $C$. cochliodes 3250}

Quantification analysis of growth regulators in the cultural fluid of $C$. cochliodes 3250 showed that the fungus was capable to synthesize auxins and gibberellins (Table 1). It also was found that $C$. cochliodes 3250 produced $8.7 \mu \mathrm{g} / \mathrm{mL}$ of cultural fluid. Furthermore the fungus was capable to synthesize gibberellic acid $56.4 \mu \mathrm{g} / \mathrm{mL}$ of cultural fluid.

Cholesterol, ergosterol and 2,4-epibrassinolide were detected in the micromycete cultural fluid. The presence of cholesterol in the cultural fluid could be evidence 
of its role as a precursor in the synthesis of 2,4-epibrassinolide (Mandava, 1998). It is known that ergosterol and 2,4-epibrassinolide contribute to increased resistance of plants to pathogenic microorganisms (Janitor, 2002). The high content of steroid derivatives indicates a high phytostimulating and protective activity of the fungus.

Table 1 Content of growth regulators in the cultural fluid of C. cochliodes 3250

\begin{tabular}{lc}
\hline \multicolumn{1}{c}{$\begin{array}{c}\text { Phytohormonal compounds } \\
\text { and their precursors }\end{array}$} & $\begin{array}{c}\text { Content in } \mathbf{C F}, \\
\boldsymbol{\mu g} / \mathbf{m L}\end{array}$ \\
\hline Indolyl-aceticacid & $8.7 \pm 0.003$ \\
Gibberellic acid & $56.4 \pm 2.12$ \\
2,4-epibrassinolide & $0.01098 \pm 0.0012$ \\
Cholesterol & $7.06 \pm 0.05$ \\
Ergosterol & $17.88 \pm 0.38$ \\
\hline
\end{tabular}

Cellulolytic complex of C. cochliodes 3250

Different types of fungi - producers of cellulose - differ in the formation way of individual components of cellulolytic complexes. The data of hydrolytic activity of components of the cellulolytic system C. cochliodes 3250 are presented in Table 2 .

Table 2 Changes in the activity of the $C$. cochliodes 3250 cellulolytic complex components

\begin{tabular}{|c|c|c|c|c|}
\hline 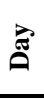 & $\begin{array}{c}\text { Exo- } \\
\text { Glucanase } \\
\text { activity, units* }\end{array}$ & $\begin{array}{l}\text { Endo-glucanase } \\
\text { activity, units } * *\end{array}$ & $\begin{array}{c}\beta \text {-glucosidase } \\
\text { activity, } \\
\text { units } * *\end{array}$ & $\begin{array}{c}\text { Pectinase } \\
\text { activity,unit } \\
\text { s*** }\end{array}$ \\
\hline 3 & $0,21 \pm 0,003$ & $0,2 \pm 0,02$ & $0,24 \pm 0,03$ & $2,21 \pm 0,11$ \\
\hline 6 & $0,26 \pm 0,02$ & $0,21 \pm 0,24$ & $0,36 \pm 0,02$ & $2,81 \pm 0,07$ \\
\hline 9 & $0,67 \pm 0,03$ & $0,52 \pm 0,02$ & $0,54 \pm 0,02$ & $2,95 \pm 0,02$ \\
\hline 12 & $0,42 \pm 0,01$ & $0,31 \pm 0,02$ & $1,02 \pm 0,03$ & $0,55 \pm 0,02$ \\
\hline
\end{tabular}

* such amount of enzyme which forms $1 \mathrm{mg}$ of reducing sugars in 60 min was taken as a unit of exoglucanase activity,

** such amount of enzymes which forms $1 \mathrm{mg}$ of reducing sugars in $30 \mathrm{~min}$ was taken as a the unit of endoglucanase and $\beta$-glucosidase activity,

*** such amount of enzyme that catalyzes conversion of $1 \mathrm{~g}$ of pectin to galacturonic acid in 60 min was taken as the unit of pectinase activity.

The exoglucanase, endoglucanase and $\beta$-glucosidase activity was established in the cultural fluid of $C$. cochliodes 3250 . The exoglucanase activity in the fungal cultural fluid was $0.67 \mathrm{U} / \mathrm{mL}$ at Day 9 of cultivation. The presence of exoglucosidase in the cultural fluid of the fungus indicated the ability of the $C$. cochliodes 3250 to degrade the crystalline form of cellulose. Endoglucanases provided hydrolysis of amorphous cellulose to cellobiose (endoglucanase activity of $C$. cochliodes 3250 was $0.52 \mathrm{U} / \mathrm{mL}$ at Day 9). $\beta$-glucosidase completed degradation of cellulose and provided hydrolysis of cellobiose to glucose $(\beta$ glucosidase activity of $C$. cochliodes 3250 was $1.02 \mathrm{U} / \mathrm{mL}$ at Day 12).

Pectinase activity of the cultural fluid of $C$. cochliodes 3250 determines the process of depolymerization of the adhesive layer of pectin between the adjacent walls of plant cells. The highest pectinase activity was recorded at Day of micromycetes cultivation and was $2.95 \mathrm{U} / \mathrm{mL}$.

Activity of succinate dehydrogenase of endophytic association of C. cochliodes 3250 / F. esculentum

Changes in the activity of succinate dehydrogenase (SDH) of the roots of the buckwheat plants over time are shown in Figure 1. It has was determined that the activity of SDH at day 20 (branching phase) of inoculated plants exceeded the control parameters by $28 \%$, and at day 40 (flowering phase) - by $13 \%$. Further there was no significant difference in the SDH activity of the control and experimental plants.

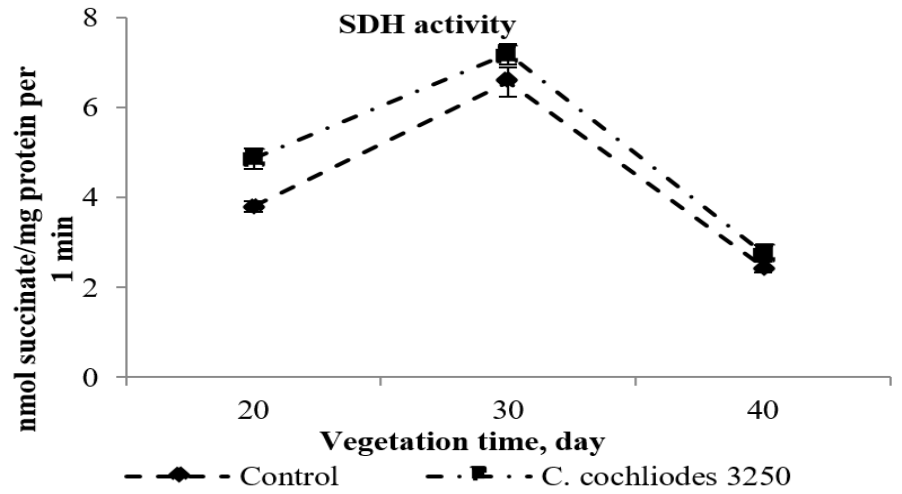

Figure 1 Activity of succinate dehydrogenase (SDH) in the roots of buckwhea under pre-sowing seed treatment by $C$. cochliodes 3250 (vegetative experiment)
Activity of acid and alkaline phosphatase of endophytic association of C. cochliodes 3250 / F. esculentum

The evaluation of alkaline phosphatase activity in mycorrhizal tissues is widely used as a parameter of the physiological efficiency of mycorrhizal infection. We found that under the treatment with $C$. cochliodes 3250 , activity of alkaline phosphatase (ALP) in the buckwheat roots was higher in the comparison to control throughout the growing season. The data is presented in Figure 2.

In addition, in control plants, the activity of the enzyme decreased over time, and in the inoculated - increased. Similar changes over time were observed for acid phosphatase (AP). The data is presented in Figure 3.

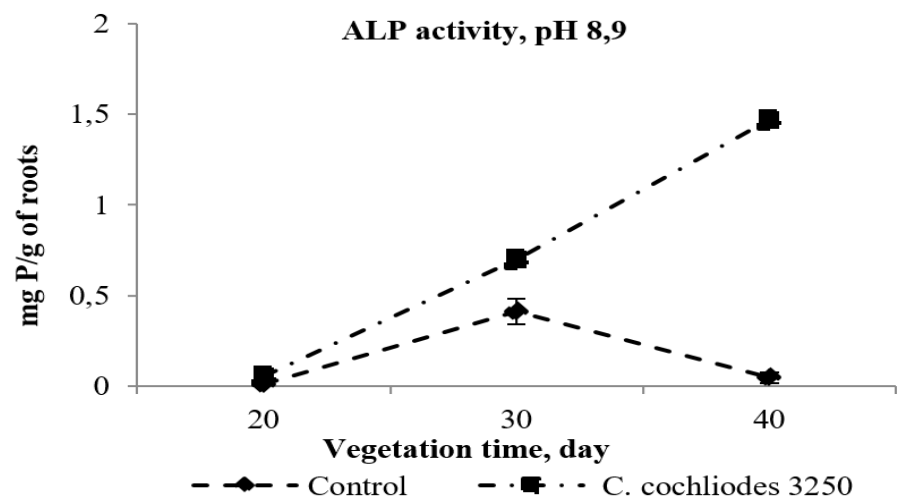

Figure 2 Activity of alkaline phosphatase (ALP) in buckwheat roots under presowing treatment of seeds by C. cochliodes 3250 (vegetative experiment)

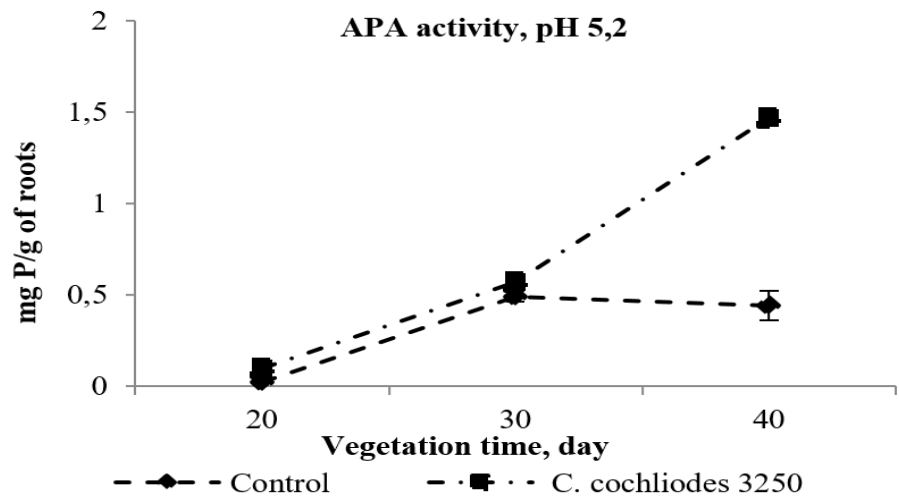

Figure 3 Activity of acid phosphatase (APA) in buckwheat roots under presowing treatment of seeds by C. cochliodes 3250 (vegetative experiment)

\section{C. cochliodes 3250 influence on buckwheat plants}

The close interaction of plants with endophytic fungi significantly affects the structure of the root system. Pre-sowing treatment of buckwheat seeds by $C$. cochliodes 3250 contributed to an increase in the surface of the plants root system. In the branching phase (Day 20), the total adsorption surface of the roots of treated plants was 2.5 times higher than in the control ones, and in the flowering phase -1.2 times (Figure 4 ). The area of the active working surface of the roots of the treated plants in the branching phase was at the control level, in the flowering phase - by $20 \%$ higher (Figure 5 ).

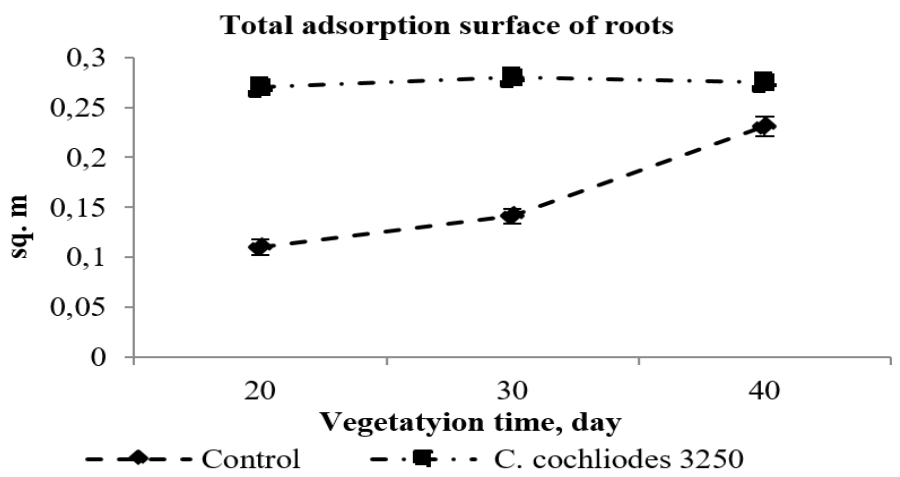

Figure 4 Total adsorption surface of root system in buckwheat plants under presowing treatment of seeds by $C$. cochliodes 3250 (vegetative experiment) 


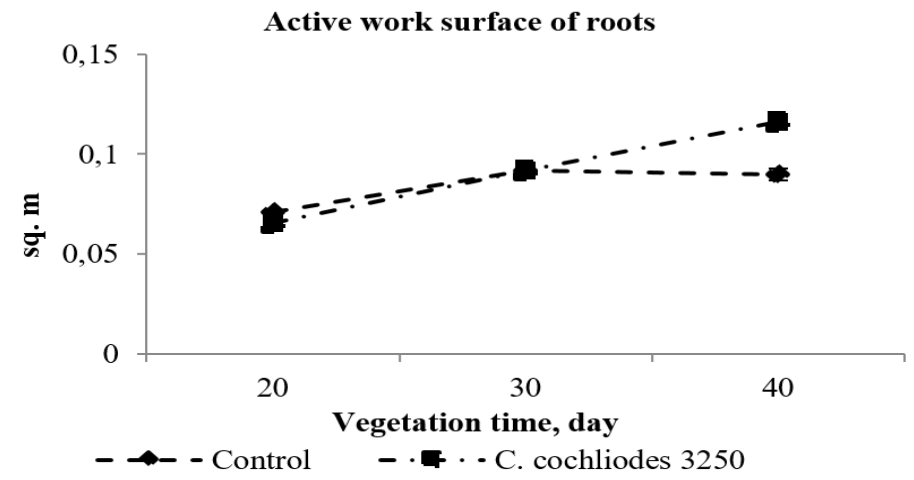

Figure 5 Area of active work surface of buckwheat plants root system under presowing treatment of seeds by $C$. cochliodes 3250 (vegetative experiment)

The increase in the adsorption surface of the roots contributed to the supply of mineral substances and had a direct impact on the plant growth improvement and development during the vegetation period. For examples, under exposure to $C$. cochliodes 3250 , the dry matter of experimental plants exceeded the control matter from 4 to $19 \%$ at different stages of vegetation. The results are presented in Figure 6.

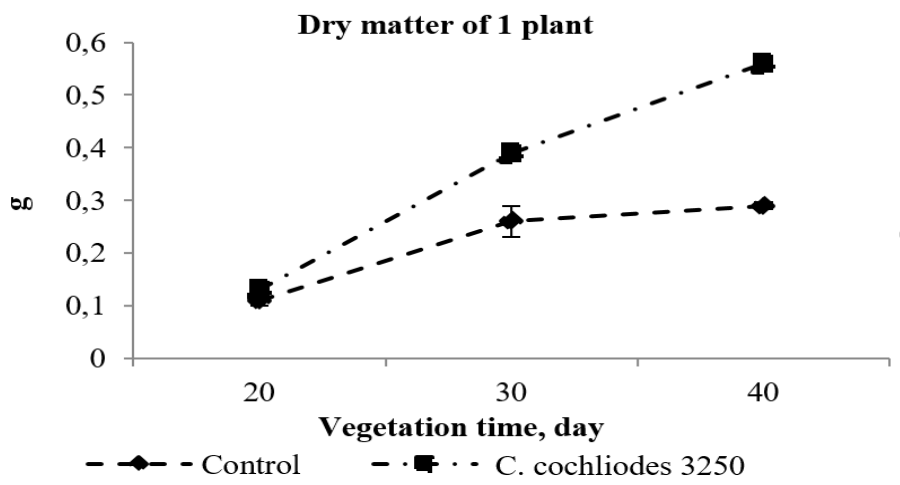

Figure 6 Dry matter of buckwheat plants under pre-sowing treatment of seeds with $C$. cochliodes 3250 (vegetative experiment)

On the Day 20 of the experiment, the height of the experimental plants exceeded the control by $26 \%$; further, the difference was less noticeable, however the inoculated plants remained capable to grow actively (Figure 7).

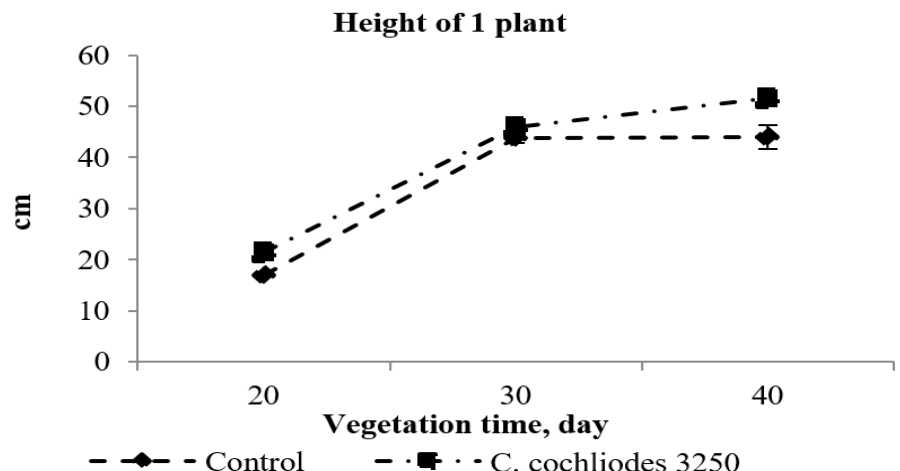

Figure 7 Height of buckwheat plant under pre-sowing treatment of seeds by C. cochliodes 3250 (vegetative experiment)

Buckwheat is characterized by an increase in green matter throughout the entire period of vegetation. It is natural that with the increase of growth processes in plants, the process of forming a photosynthetic apparatus is accelerated.

In the vegetative experiment with buckwheat seed (Figure 8) we noted that the largest difference between the areas of the treated leaf surface and control plants was observed in the budding phase (Day 30) and was $11 \%$.

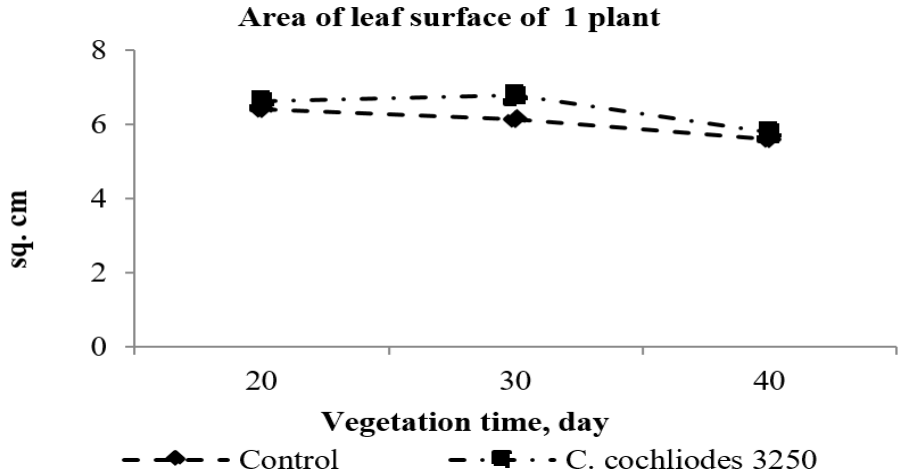

Figure 8 Area of buckwheat plants leaf surface under pre-sowing treatment of seeds by C. cochliodes 3250 (vegetative experiment)

In addition, the formation of the endophytic association positively affected the productive performance of photosynthesis.

The obtained results showed an increase in the content of chlorophyll $a$ in the leaves of inoculated buckwheat by $23 \%$ on the Day 20 (branching phase), and by $6 \%$ on the Day 30 (budding phase). The obtained results are presented in Figure

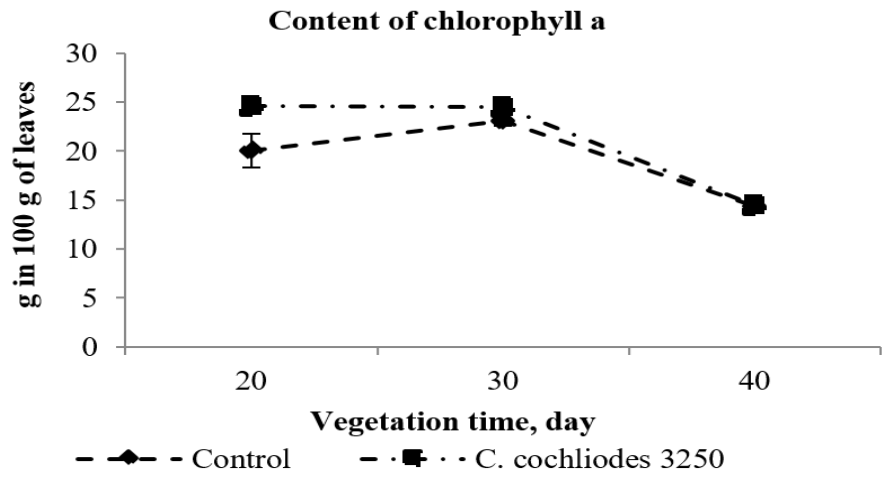

Figure 9 Content of chlorophyll $a$ in the buckwheat plants leaves under presowing treatment of seeds by C. cochliodes 3250 (vegetative experiment)

The highest content of chlorophyll $b$ was observed on the Day 30, as shown in Figure 10. Further, the content of chlorophylls $a$ and $b$ decreased and after Day 40 (flowering phase), no difference was found between the control and experimental plants.

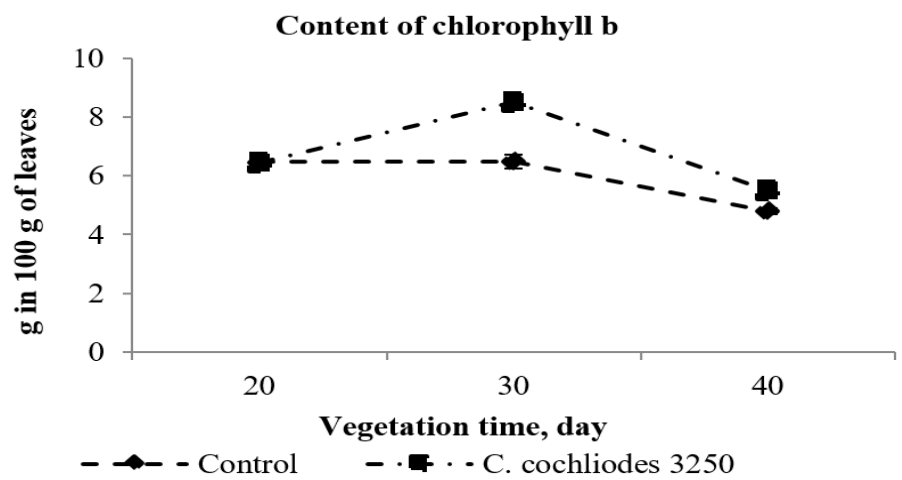

Figure 10 Content of chlorophyll $b$ in the buckwheat plants leaves of under presowing treatment of seeds by $C$. cochliodes 3250 (vegetative experiment)

\section{DISCUSSION}

There is an evidence that soil fungi are able to survive on root surface and penetrate into root fibrils and rhizoderm cells forming endophytic associations (Chaves et al., 2009; Cevnik et al., 2000; Harrison, 2005; Hause, Fester, 2005 Ding et al., 2006; El-Zayat, 2008; Hata et al., 2010). Endophytism phenomenon of beneficial saprophyte fungi on plant root is a powerful factor for plant growth, metabolic processes activation and, as a result, subsequent macroorganism development. Microbial groups in root zone differ both in different species of plants (Innes et al., 2004; Batten et al., 2006) and within one species (Kowalchuk et al., 2006), as well as during ontogenesis of the individual plant (Weisskopf et al., 2006). The interaction between the microbiota and the root system is dynamic and based on co-evolutionary mechanisms (Broeckling et al., 2008). 
As a result of our studying, we found out some interactions between plant and fungus symbiont provided in Figure 11

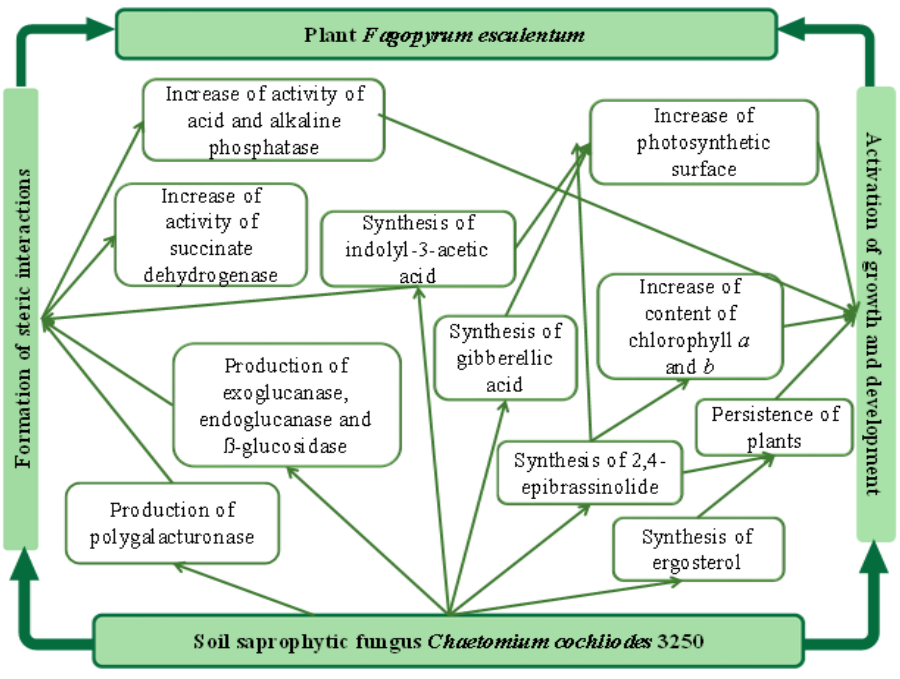

Figure 11 Functional relationship between micro- and macro-symbionts of the endophytic association $C$. cochliodes 3250/Fagopyrum esculentum

Various plant exudates and microbial metabolites such as enzymes and biologically active substances played an important role in formation of associations between soil fungi and plants (Yuan et al., 2010, Aly et al., 2010) Particularly it was established that the synthesis of physiologically active forms of auxins was typical for the majority of soil microorganisms forming assotiative relationships with plant (Iutynska, Ponomarenko, 2010). Metabolic products of C. cochliodes 3250 with auxin nature that we had found could stimulate cell growth by stretching, which was important for the conducting bundles formation, cambium and the additional roots formation.

The practical $C$. cochliodes 3250 usage was efficient due to the ability of its exogenous gibberellins to stimulate stem growth, increase the number of flower and the size of the fruits, change the shape and size of flowers, accelerate seed germination, etc.

It is known that under the influence of phytohormonal substances synthesized by a microsymbiont, the photosynthetic activity of the plant improves, in particular, the amount of photosynthetic pigments increases (Smith, Read 2012). We also found that survival of saprotrophic fungus $C$. cochliodes 3250 living on buckwheat root zone contributed to improved nutrition, activation of photosynthesis processes and increased of the total content of chlorophylls in plant leaves.

In plants adaptation to adverse environmental factors process, several cellular signalling systems, phytohormones and stress metabolites, are involved among which brassinosteroids draw attention of researchers. Brassinosteroids are physiologically active at very low concentrations $\left(10^{-6}\right.$ to $\left.10^{-12}\right)$, which distinguishes them from other classes of phytohormones (Sakurai, Fujioka 1993). They can affect a wide range of morphological and physiological reactions: stimulate the growth of pollen tubes, change the shape of plant leaves, inhibit root growth, stimulate the synthesis of ethylene and increase the resistance of plants to abiotic stresses (Dragovoz et al., 2009; Tyuterov, 2015; Sharikova 2001; Brass 1999). Previous studies showed that $C$. cochliodes 3250 was an active antagonist, and the mechanism of its action on pathogenic microorganisms was defined as direct competition (Nadkernychny et al., 1995). It can be assumed that the synthesis of 2,4-epibrassinolide also played a role in the competitive relations process, stimulating the growth of the plant root system and its potential for self-defence.

The presence of cholesterol in the cultural fluid may be an evidence of its role as a precursor in the synthesis of 2,4- epibrassinolide (Mandava, 1998). Plants use specific induced reactions that are activated only in response to contamination with a specific pathogen in order to protect from phytopathogens that overcome constitutional barriers. The high content of steroid derivatives indicates a high phytostimulating and protective activity of the fungus (Conrad, 2011). Receptor recognition of signalling molecules (ergosterol), produced by saprophytic fungus, promotes the development of induced systemic resistance of plants against phytopathogens of different origin (Olsson et al., 2003).

Some authors noted the presence of complex enzyme set in fungi -endophytes cellulase, hemicellulose, polyphenol oxidase, polygalacturonase, which decompose plant tissues (Antonyak et al., 2013). Different species of fungi producers of cellulose - differ in the formation way of the cellulolytic complexes individual components. The high cellulase activity of $C$. cochliodes 3250 stipulates its ability to penetrate the plant tissues.

Changes in hyphae membranes' structures of arbuscular fungi, when penetrating the intercellular space, were associated with the enzymes - pectinase (Gianinazzi-Pearson et al., 1981). That fact was confirmed by their biochemical detection in spores and free mycelium (Lobanok et al., 1988). Among the microscopic fungi capable to significantly produce the pectolytic enzymes were the representatives of the Mucor, Rhizopus, Aspergillus, Penicillum, Fusarium, Alternaria and other genera (Agrios, 2005; Avdeeva et al., 2010, Collmer, Keen, 1986). We have also detected polygalacturonase activity of the cultural fluid of C. cochliodes 3250 , which determined the process of depolymerisation of the adhesive layer of pectin between the adjacent walls of plant cells.

Penetration into the root of plants and formation of appropriate mycorrhizal structures was accompanied with increased activity of the enzyme succinate dehydrogenase (SDH) (Sylvia, 1988; Hamel et al., 1990; van Aarle et al., 2005). The interdependence of symbiotic activity and SDH activity were confirmed by the histochemical staining of external (Hamel et al., 1990; Vierheiling, Ocompo, 1991) and internal (Macdonald, Lewis, 1978; Ocampo, Barea, 1985; Saito et al. 1993; Tawaraya et al., 1994) hyphae of arbuscular fungi for wheat, soybean and onions plants. SDH is a multifunctional enzyme complex, involved in the course of catabolic and anabolic processes. The enzyme catalyzed the oxidation of succinate to fumarate in the tricarboxylic acid cycle, and even the recovery of fumarate to succinatein in higher organisms (Eprintsev et al., 2007). At the same time, it was closely connected with the internal membrane of mitochondria and was a component of the Krebs cycle and the electron transport chain. Therefore its regulation was related to functioning of two processes of the cell oxidative metabolism (Pastore et al., 2001).

In the modern literature buckwheat is characterized as a classic non-mycorrhizal plant (Harley, Harley, 1987; Gai et al., 2006; Wang, Qiu, 2006). At the same time, published results of the molecular genetic analysis of fungi isolated from edaposphere and rhizosphere of culture, with DNA fragment sequences, were close to species of Glomusgenus (Likar et al., 2008).

In our studies with common buckwheat, increase in SDH activity aligned with the active development of $C$. cochliodes 3250 on the roots of culture. Both signs indicate the formation of the endophytic association $C$. cochliodes $3250 /$ common buckwheat

The close interaction between plants and endophytic fungi that produce growthstimulating substances significantly affects the structure of the root system. Thus, inoculation of plants with fungi of the genus Trichoderma was accompanied by an increase in the biomass of the roots, an increase in the intensity of the development of lateral roots and root fibrils (Contreras-Cornejo et al., 2009). Our results confirmed that the introduction of $C$. cochliodes 3250 micromycetes into the root zone of buckwheat caused the basic physiological responses of plants to the formation of a symbiotic system: an increase in the total and active working surface of the roots.

It is known that the mycorrhization of plants increases the supply of phosphorus to the roots in 3-5 times (Smith, Read, 2008). For example, "mycorrhizaspecific" alkaline phosphatases (ALPs) was found in vacuoles of mature arbusculae, intercellular hyphae and in the hyphal glomus of Paris-type mycorrhiza (van Aarle et al., 2005). Previously, it was believed that ALP activity was limited by the internal structures of the root AM (Tisserant et al., 1993) However, appropriate enzyme was also found in free mycelium (Aono et al., 2004). The evaluation of alkaline phosphatase activity in mycorrhizal tissues was widely used as a parameter of the physiological efficiency of mycorrhizal infection. Functioning of acid phosphatase activity (AP) allowed maintaining the mobility of a large part of inorganic phosphorus during maturation of the crop (Turner, Plaxton, 2001). ALP and AP widespread in cells and played an important role in the metabolism of inorganic phosphates and cellular metabolism (Tabaldi et al., 2007; Mishra, Dubey, 2008). The evaluation of alkaline phosphatase activity in plant tissues colonized by mycorrhizal fungi is now widely used as a parameter of the physiological efficiency of mycorrhization. We revealed the increase in the activity of acid and alkaline phosphatase during the whole vegetation period in the buckwheat roots under the action of $C$. cochliodes 3250 , indicating the efficiency of the formed symbiosis.

\section{CONCLUSION}

This study focused on features of the interaction between soil fungus $C$. cochliodes 3250 and buckwheat plants.

It was also shown for the first time that $C$. cochliodes 3250 was capable to produce 2,4-epibrassinolide $(0.011 \mu \mathrm{g} / \mathrm{mL}$ of cultural fluid), which played an important role in plant resistance to pathogens and ergosterol $(17.88 \mu \mathrm{g} / \mathrm{mL}$ of cultural fluid). In addition, the fungus synthesized phytohormonal substances: indolyl-acetic acid $(8.7 \mu \mathrm{g} / \mathrm{mL}$ of cultural fluid) and gibberellic acid $(56.4 \mu \mathrm{g} / \mathrm{mL}$ of cultural fluid). The indolyl 3-acetic acid and ergosterol synthesized by the fungus could be the main mediator molecules in the formation of $C$. cochliodes 3250 symbiotic systems with plants.

The exoglucanase, endoglucanase and $\beta$-glucosidase activity in the cultural fluid of $C$. cochliodes 3250 were established. $C$. cochliodes 3250 was capable to synthesize enzymes: exoglucanase $(0.67 \mathrm{U} / \mathrm{mL})$, endoglucanase $(0.52 \mathrm{U} / \mathrm{mL}), \beta$ glucosidase $(1.02 \mathrm{U} / \mathrm{mL})$ and polygalacturonase $(2.95 \mathrm{U} / \mathrm{mL})$, which was very important for its penetration into the plant root.

The action of fungi in the buckwheat roots increased the activity of succinate dehydrogenase (by $28 \%$ ), acidic (by $326 \%$ ) and alkaline (by 391\%) phosphatase 
during the whole vegetation period indicating the efficiency of the formed symbiosis.

It was found that pre-sowing treatment of buckwheat seeds by $C$. cochliodes 3250 fungus causes the basic physiological plants responses that are characteristic features for the symbiotic system formation. Namely they are increase of the total (by 145\%) and active working (by 7\%) root surface, increase of plant length (by 27\%), leaf area (11\%) and content of chlorophylls $a$ and $b$ $(17 \%)$.

Acknowledgments: The work was performed within the framework of the state order for fundamental studies No. 0116U003068. We are grateful to Dr. Ihor Drahovoz (Department of Antibiotics of D.K. Zabolotny Institute of Microbiology and Virology of the National Academy of Sciences of Ukraine) for help in determining the quantitative composition of the growth-regulating substances, metabolites of the fungus $C$. cochliodes 3250 .

\section{REFERENCES}

ARNOLD, A.E. HERRE, E.A. 2003. Canopy cover and leaf age affect colonization by tropical fungal endophytes: Ecological pattern and process in Theobroma cacao (Malvaceae). Mycologia, 95(3), 388-98. http://dx.doi.org/10.2307/3761880

WALLER, F. ACHATZ, B. BALTRUSCHAT, H. FODOR, J. BECKER, K FISCHER, M. HEIER, T. HÜCKELHOVEN, R. NEUMANN, C. VON WETTSTEIN, D. FRANKEN, P. KOGEL K.H. 2005. The endophytic fungus Piriformospora indica reprograms barley to salt-stress tolerance, disease resistance, and higher yield. Proceedings of the National Academy of Sciences of the United States of America, 102(38), 13386-13391. http://dx.doi.org/10.1073/pnas.0504423102

MARQUEZ, L.M. REDMAN, R.S. RODRIGUEZ, R.J. ROOSSINCK, M.J. 2007. A virus in a fungus in a plant: three-way symbiosis required for thermal tolerance. $\quad$ Science, $316(5822), \quad 513-515$ http://dx.doi.org/10.1126/science.1136237

ANTONYAK, G.L. KALINETS-MAMCHUR, Z.I. DUDKA, I.O. BABICH, N.O. PANAS, N.E. 2013. Ecology fungi: monograph. Lviv: Lviv Ivan Franko National University. 628 p. ISBN978-617-10-0050-6.

LUTOVA, L.A. PROVOROV, N.A. TIKHODEYEV, O.N. TIKHONOVICH, I.A. KHOJAYOVA, L.T. SHISHKOVA, S.O. 2000. Genetic of plant development. St. Petersburg: Science. 539 p.

SPATAFORA, J.W. SUNG, G.H. SUNG, J.M. HYWEL-JONES, N.L. WHITE, JF. JR. 2007. Phylogenetic evidence for an animal pathogen origin of ergot and the grass endophytes. Molecular Ecology, 16(8), 1701-1711. http://dx.doi.org/10.1111/j.1365294X.2007.03225.X

CHAREST, C. DALPE, Y. BROWN, A. 1993. The effect of vesicular-arbuscula mycorrhizae and chilling on two hybrids of Zea meys L. Mycorrhiza, 4(2), 89-92. http://dx.doi.org/10.1007/BF00204064

CEVNIK, M. JURS, M. VODNIK, D. 2000. Filamentous fungi associated with the fine roots of Erica herbacea L. from the area influenced by the Zerjav lead smelter (Slovenia). Phyton, (4), 61-64.

TSAVKELOVA, E.A. ALEXANDROVA, A.V. CHERDYNTSEVA, T.A KOLOMEYTSEVA, G.K. NETRUSOV, A.I. 2005. Associative micromycetes of tropical Vietnamese orchids. Mycology and Phytopathology, 39, 46-52.

SUBRAMANIAN, K.S. CHAREST, C. 1997. Nutritional, growth, and reproductive responses of maize (Zea mays L.) to arbuscular mycorrhizal inoculation during and after drought stress at tasseling. Mycorrhiza, 7(1), 25-32. http://dx.doi.org/10.1007/s005720050159

HAUSE, B. FESTER, T. 2005. Molecular and cell biology of arbuscular mycorrhizal symbiosis. Planta, 221(2), 184-196. http://dx.doi.org/10.1007/s00425-004-1436-X

DING, G. SONG, Y.C. CHEN, J.R. XU, C. GE, H.M. WANG, X.T. TAN, R.X. 2006. Chaetoglobosin U, a cytochalasan alkaloid from endophytic Chaetomium globosum IFB-E019. Journal of Natural Products, 69(2), 302-304 http://dx.doi.org/10.1021/np050515+

EL-ZAYAT, S.A. 2008. Preliminary studies on laccase production by Chaetomium globosum an endophytic fungus in Glinus lotoides. AmericanEurasian Journal of Agricultural \& Environmental Sciences, 1(3), 86-90.

HATA, S. KOBAE, Y. BANBA, M. 2010. Interactions between plants and arbuscular mycorrhizal fungi. International Review of Cell and Molecular Biology, 281, 1-48. http://dx.doi.org/10.1016/S19376448(10)81001-9

KOPYLOV, E.P. 2013. Soil saprophytic fungi are natural regulators of plan growth, development and resistance to pathogens. AV Akademikerverlag $\mathrm{GmbH}$ \& Co.KG: Palmarium academic publishing. 2013. 104 p.

SINGH, D.P. SINGH, H.B. PRABHA, R. Plant-Microbe Interactions in AgroEcological Perspectives. Singapore: Springer Nature. 2017. 763 p.

RANA, K.L. KOUR, D. YADAV, A.N. KUMAR, V. DHALIWAL, H.S. 2016 Biotechnological applications of endophytic microbes associated with barley (Hordeum vulgare L.) growing in Indian Himalayan regions, 86th Annual Session of NASI \& Symposium on "Science, Technology and Entrepreneurship for Human Welfare in The Himalayan Region”, 2-4 Dec 2016. Allahabad: Lajpatrai Road; 2016. p. 80
RANA, K.L. YADAV, A.N. KOUR, D. KUMAR, V. Dhaliwal, H.S. 2016 Endophytic microbes from wheat: diversity and biotechnological applications for sustainable agriculture, 57th association of microbiologist of India \& international symposium on "Microbes and Biosphere: What's New What's Next”; 24-27 Nov 2016. Assam: Gauhati University. p. 453.

YADAV, A.N. KUMAR, R. KUMAR, S. KUMAR, V. SUGITHA, T.C.K SINGH, B. SINGH, V. C. SINGH, H. D., KUMAR, A. S. 2017. Beneficial microbiomes: Biodiversity and potential biotechnological applications for sustainable agriculture and human health. Journal of Applied Biology and Biotechnology, 5(6), 1-13. http:/dx.doi.org/10.7324/JABB.2017.50607.

SPAGNOLETTI, F. TOBAR, N.E. FERNANDEZ, A. PARDO, D CHIOCCHIO, V.M. LAVADO, R.S. 2017. Dark septate endophytes present different potential to solubilize calcium, iron and aluminum phosphates. Applied Soil Ecology, 111, 25-32. http://dx.doi.org/10.1016/j.apsoil.2016.11.010

HARLEY, J.L. HARLEY, E.L. 1987 A check-list of mycorrhiza in the British flora. New Phytologist, 105(1), 1-102. http://dx.doi.org/10.1111/j.1469 8137.1987.tb00674.x

GAI, J.P. FENG, G. CAI, X.B. CHRISTIE, P. LI, X.L. 2006. A preliminary survey of the arbuscular mycorrhizal status of grassland plants in southern Tibet. Mycorrhiza, 16(3), 191-196. http:/dx.doi.org/10.1007/s00572-005-0032-7.

WANG, B. QIU, Y.L. 2006. Phylogenetic distribution and evolution of mycorrhizas in land plants. Mycorrhiza, 16(5), 299-363. http://dx.doi.org/10.1007/s00572-005-0033-6

LIKAR, M. BUKOVNIK, U. KREFT, I. CHRUNGOO, N.K. REGVAR, M 2008. Mycorrhizal status and diversity of fungal endophytes in roots of common buckwheat (Fagopyrum esculentum) and tartary buckwheat (F. tataricum) Mycorrhiza, 18(6-7), 309-315. http://dx.doi.org/10.1007/s00572-008-0181-6

ZHANG, F. SOYTONG, K. 2013. Development of a non-metal nanoparticle as carrier of bio-active compounds from Chaetomium cochliodes. KMITL, 28-29, 453-460.

SIBOUNNAVONG, P. CHAROENPORN, C. KANOKMEDHAKUL, S SOYTONG, K. 2011. Antifungal metabolites from antagonistic fungi used to control tomato wilt fungus Fusarium oxysporum $f$. sp. Lycopersici. African Journal of Biotechnology, 10(85), 19714-19722.

HWANG, E.I. YUN, B.S. KIM, Y.K. KWON, B.M. KIM, H.G. LEE, H.B. BAE, K.S. KIM, S.U. 2000. Chaetoatrosin A, a novel chitin synthase II inhibitor produced by Chaetomium atrobrunneum. Journal Antibiot (Tokyo), 53(3), 248255. http://dx.doi.org/10.7164/antibiotics.53.248

KOBAYASHI, M. YOSHIMURA, S. KINOSHITA, T. HASHIMOTO, M HASHIMOTO, S. TAKASE, S. FUJIE, A. HINO, M. HORI, Y. 2005 FR207944, an antifungal antibiotic from Chaetomium sp. 217 II. Isolation and structure elucidation. Bioscience, Biotechnology, and Biochemistry, 69(5), 10291032. http://dx.doi.org/10.1271/bbb.69.1029

GEIGER, W.B. CONN, J.E. WAKSMAN, S.A. 1944 Chaetomin, a new antibiotic substance produced by Chaetomium cochliodes. II. Isolation and concentration. Journal Bacteriology, 48(5), 531-536.

PIYASENA， K.G.N.P. WICKRAMARACHCHI, W.A.R.T. KUMAR, N.S JAYASINGHEET, L. FUJIMOTO, Y. 2015. Two phytotoxic azaphilone derivatives from Chaetomium globosum, a fungal endophyte isolated from Amaranthus viridis leaves. Mycology, 6(3-4), 158-160. http://dx.doi.org/10.1080/21501203.2015.1089332

BAI, H. WU, L. YANG, T. LI, G. 2015. Isolation and identification of secondary metabolites from fungus Chaetomium gracile and their antimicrobial activities Chinese Journal of Applied and Environmental Biology, 21(2), 274-278. http://dx.doi.org/10.3724/SP.J.1145.2014.08020

KOPILOV, E.P. NADKERNICHNY, S.P. ADAMCHUK-CHALA, N.I. 2010 Saprophytic soil fungus Chaetomium cochliodes Palliser as biotic factor of effective associations forming between azospirillum bacteria and spring whea plants. Bulletin of Kharkiv national agrarian university (Biology series), 1(19), 91-100.

KOPILOV, E.P. NADKERNICHNY, S.P. 2008. Effectiveness of symbiotic interaction of Chaetomium cochliodes Palliser with soybean plants. Physiology and biochemistry of cultivated plants, 40(3), 260-267.

VOLKOGON, V.V. VOROBEY, Yu.O. NADKERNICHNA, O.V. 2015. Catalog of microorganisms cultures. Chernihiv: publisher Braginets O.V. 48 p.

BELYAVSKAYA, L.A. GALAGAN, T.A. BOLTOVSKAYA, E.V KOZYRITSKAYA, B.E. VALAGUROVA, E.B. SIGAREVA, D.D. 2009. Antinematode properties of Strepmyces avemitilis UKM Ac-2179 and its avermectin complex - avercom. Agrarian Science, 1, 29-33.

BILAY, V.I. 1982. Methods of experimental mycology: Handbook. Kiev: Naukova Dumka. 549 p.

RESYAPKIN, V.I. SLYSHKOV, V.S. PLANT, I.B. BURDA, V.N. SUSHKO, L.I. ROMANCHUK, E.I. 2009. Laboratory Workshop on Biochemistry and Biophysics. Grodno: GrSU. 175 p.

ERMAKOV, A.I. ARASIMOVICH, V.V. SMIRNOVA-IKONNIKOVA, M.I. YAROSH, N. P. LUKOVNIKOVA, G.A. 1972. Methods of biochemical studies of plants. Leningrad: Kolos. $456 \mathrm{p}$

GORODNIY, M.M. LISOVAL, A.P. BIKIN, A.V. 2005. Agrochemical analysis Kyiv: Ariste. 476 p. ISBN 9668458400. 
TRETYAKOV, NN KARNAUKHOV, T.V. PANICHKIN, LA and other 1990. Workshop on plant physiology. Moscow: Agropromizdat. $271 \mathrm{~s}$.

GRODZINSKY, A.M. GRODZINSKY, D.M. 1973. A short guide to the physiological roslin. Kiev: Naukova Dumka. 567 p.

MANDAVA, N.B. 1998. Plant growth-promoting brassinosteroids. Annual Review of Plant Physiology and Plant Molecular Biology, 39, 23-52. http://dx.doi.org/10.1146/annurev.pp.39.060188.000323

JANITOR, A. 2002. Growth of mycelia of phytopathogenic fungi after application of abscisic acid in vitro conditions. Plant Protection Science, 38(3), 94-97. http://dx.doi.org/ 10.17221/4857-PPS

CHAVES, S. NETO, M. TENREIRO, R. 2009. Insect-symbiont systems: from complex relationships to biotechnological applications. Biotechnology Journal , 4(12), 1753-1765. http:/dx.doi.org/10.1002/biot.200800237.

HARRISON, M.J. 2005. Signaling an the arbuscular mycorrhizal symbiosis Annual Review of Plant Physiology and Plant Molecular Biology, 59, 19-42. http://dx.doi.org/10.1146/annurev.micro.58.030603.123749

INNES, L. HOBBS, P.J. BARDGETT, R.D. 2004. Impacts of individual plant species on rhizosphere microbial communities in soils of different fertility. Biology and Fertility of Soils, 40(1), 7-13. http://dx.doi.org/10.1007/s00374-0040748-0

BATTEN, K.M. SCOW, K. DAVIES, K.F. HARRISON, S.P. 2006. Two invasive plants alter soil microbial community composition in Serpentine Grasslands. Biological Invasions, 8(2), 217-230. http://dx.doi.org/10.1007/s10530-004-3856-8

KOWALCHUK, G.A. HOL, W.H.G., VAN VEEN, J.A. 2006. Rhizosphere fungal communities are influenced by Senecio jacobaea pyrrolizidine alkaloid content and composition. Soil Biology and Biochemistry, 38(9), 2852-28529. http://dx.doi.org/10.1016/j.soilbio.2006.04.043

WEISSKOPF, L. TOMASI, N. SANTELIA, D. MARTINOIA, E. LANGLADE, N.B. TABACCHI, R. ABOU-MANSOUR, E. 2006. Isoflavonoid exudation from white lupin roots is influenced by phosphate supply, root type and cluster-root stage. New Phytologist, 171(3), 657-668. http://dx.doi.org/10.1111/j.14698137.2006.01776.x

BROECKLING, C.D. BROZ, A.K. BERGELSON, J. MANTER, D.K VIVANCO, J.M. 2008. Root exudates regulate soil fungal community composition and diversity. Applied Environmental Microbiology, 74(3), 738-744. http://dx.doi.org/10.1128/AEM.02188-07

YUAN, Z.L. ZHANG, C.L. LIN, F.C. KUBICEK, C.P. 2010. Identity, diversity, and molecular phylogeny of the endophytic mycobiota in the roots of rare wild rice (Oryza granulate) from a nature reserve in Yunnan, China. Applied Environmental Microbiology, $\quad 76(5), \quad 1642-1652$. http://dx.doi.org/10.1128/AEM.01911-09

ALY, A. DEBBAB, A. KJER, J. PROKSCH, P. 2010. Fungal endophytes from higher plants: a prolific source of phytochemicals and other bioactive natural products. Fungal Diversity, 41(1), 1-16. http://dx.doi.org/10.1007/s13225-0100034-4

IUTYNSKA, G.O., PONOMARENKO, S.P. 2010. Bioregulation of microbioalplant systems: Monograph. Kyiv: Nichlava. 464 p.

SMITH, S.E. READ, D.J. 2012. Mycorrhizal symbiosis. Moscow: KMK scientific partnership. $776 \mathrm{p}$.

SAKURAI, A. FUJIOKA, S. 1993. The current status of physiology and biochemistry of brassinosteroids. Plant Growth Regulation, 13, 147-159.

DRAGOVOZ, I.V. YAVORSKA, V.K. ANTONIUK, V.P. KURCHII, B.A 2009. Hormonal substances produced by microorganism association from ginseng roots Physiology and biochemistry of cultivated plants, 41(5), 393-399.

TYUTEREV, S.L. 2015. Ecologically safe inducers of plant resistance to diseases and physiological stresses. Plant Protection News, 1(83), 3-12.

SHARIKOVA, F.M. 2001. Nonspecific resistance of plants to stress factors and its regulation. Ufa: Gilem, $160 \mathrm{p}$.

BRASS, D. 1999. Biological effects of brassinosteroids. Critical Reviews in Biochemistry and Molecular Biology, 34, 339-358. http://dx.doi.org/10.1080/10409239991209345

NADKERNICHNY, SP. OKHRIMENKO, G.I. IVASHCHENKO. G.V. 1995. Antagonistic properties of Chaetomium cochlioides Pallisser in relation to pathogens of lupine disease. Microbiology Journal, 57 (1), 48-68.

CONRAD, V. 2011. Molecular aspects of defense priming. Trends in Plant Science, 16, 524-531. http://dx.doi.org/ 10.1016/j.tplants.2011.06.004

OLSSON, P.A. LARSSON, L. BAGO, B. WALLANDER, H. VAN AARLE, I.M. 2003. Ergosterol and fatty acids for biomass estimation of mycorrhizal fungi. New Phytologist, 159(1), 7-10. http://dx.doi.org/10.1046/j.14698137.2003.00810.x

GIANINAZZI-PEARSON, V. MORANDI, D. DEXHEIMER, J. GIANINAZZI, S. 1981. Ultrastructural and ultracytochemical features of a Glomus tenuis Mycorrhiza, 88(4), 633-9. http://dx.doi.org/10.1111/j.1469-8137.1981.tb01739.x LOBANOK, A.G. BABITSKAYA, V.G. BOGDANOVSKAYA, J.N. 1988 Cellulose-based microbial synthesis: Protein and other valuable products. Minsk: Science and technology. $261 \mathrm{p}$.

AGRIOS, G.N. 2005. Plant Pathology. New York: Academic Press. 922 p.
AVDEEVA, L.V. OSADCHAYA, A.I. SAFRONOVA, L.A. ILYASH, V.M KHARKHOTA, M.A. 2010. Pectolitic bacteria activity of genus Bacillus. Microbiology and Biotechnology, 3, 71-8.

COLLMER, A. KEEN, N.T. 1986. The role of pectic enzymes in plant pathogenesis. Annual Review of Phytopathology, 24, 383-409. http://dx.doi.org/10.1146/annurev.py.24.090186.002123

SYLVIA, D.M. 1988. Activity of external hyphae of vesicular-arbuscular mycorrhizal fungi. Soil Biology and Biochemistry, 20(1), 39-43. http://dx.doi.org/doi.org/10.1016/0038-0717(88)90124-1

HAMEL, C. FYLES, H. SMITH, D.L. 1990. Measurement of development of endomycorrhizal mycelium using three different vital stains. New Phytologist, 115(2), 297-302. http://dx.doi.org/10.1111/j.1469-8137.1990.tb00455.x

VAN AARLE, I.M. CAVAGNARO, T.R. SMITH, S.E. SMITH, F.A DICKSON, S. 2005. Metabolic activity of Glomus intraradices in Arum- and Paris-type arbuscular mycorrhizal colonization. New Phytologist..166(2), 611618. http://dx.doi.org/10.1111/j.1469-8137.2005.01340.x

VIERHEILIG, H. OCAMPO, J.A. 1991 Receptivity of various wheat cultivars to infection by VA-mycorrhizal fungi as influenced by inoculum potential and the relation of VAM-effectiveness to succinic dehydrogenase activity of the mycelium in the roots. Plant and Soil, 133(2), 291-296.

MACDONALD, R.M. LEWIS, M. 1978. The occurrence of some acid phosphatases and dehydrogenases in the vesicular-arbuscular mycorrhizal fungus Glomus mosseae. New Phytologist, 80(1), 135-141. http://dx.doi.org/10.1111/j.1469-8137.1978.tb02273.x

OCAMPO, J.A. BAREA, J.M. 1985. Effect of carbamate herbicides on VA mycorrhizal infection and plant growth. Plant and Soil, 85(3), 375-383

SAITO, M. STRIBLEY, D.P. HEPPER, C.M. 1993. Succinate dehydrogenase activity of external and internal hyphae of a vesicular-arbuscular mycorrhizal fungus, Glomus mosseae (Nicol. \& Gerd.) Gerdmann and Trappe, during mycorrhizal colonization of roots of leek (Allium porrum L.), as revealed by in situ histochemical staining. Mycorrhiza, 4(2), 59-62

TAWARAYA, K. SAITO, M. MORIOKA, M. WAGATSUMA, T. 1994. Effect of phosphate application to arbuscular mycorrhizal onion on the development and succinate dehydrogenase activity of internal hyphae. Soil Science and Plant Nutrition, 40(4), 667-673. http://dx.doi.org/10.1080/00380768.1994.10414306 EPRINTSEV, A.T. POPOV, V.N. SHEVCHENKO, M.Yu. 2007. The glyoxylate cycle: a universal adaptation mechanism? Moscow: Academic Book; 2007.228 p. PASTORE, D. TRONO, D. LAUS, M.N. 2001. Insights into the regulation of plant succinate dehydrogenase on the role of the proton motive fore. The Journal Of Biological Chemistry, 276(35), 32567-3274.

CONTRERAS-CORNEJO, H.A. MACÍAS-RODRÍGUEZ, L. CORTÉSPENAGOS, C. LÓPEZ-BUCIO, J. 2009. Trichoderma virens, a plant beneficial fungus, enhances biomass production and promotes lateral root growth through an auxin-dependent mechanism in Arabidopsis. Plant Physiology, 149(3), 15791592. http://dx.doi.org/10.1104/pp.108.130369

SMITH, S.E. READ, D.J. 2008. Mycorrhizal Symbiosis. 2hd ed. London: Academic Press. 605 p.

TISSERANT, I.B. GIANINAZZI-PEARSON, V. GIANINAZZI, S GOLLOTTE, A. 1993. In planta histochemical staining of fungal alkaline phosphatase activity for analysis of efficient arbuscular mycorrhizal infections. Mycological Research, 97(2), 245-250. http://dx.doi.org/10.1016/S09537562(09)80248-7

AONO, T. MALDONADO-MENDOZA, I.E. DEWBRE, G.R. HARRISON, M.J. SAITO, M. 2004. Expression of alkaline phosphatase genes in arbuscular mycorrhizas. New Phytologist, 162(2), 525-534. http://dx.doi.org/10.1111/j.14698137.2004.01041.X

TURNER, W.L. PLAXTON, W.C. 2001. Purification and characterization of banana fruit acid phosphatase. Planta. 2001 214(2), 243-249. http://dx.doi.org/10.1007/s004250100607

TABALDI, L.A. RUPPENTHAL, R. CARGNELUTTI, D. MORSCH, V.M PEREIRA, L.B. SCHETINGER, M.R.C. 2007. Effects of metal elements on acid phosphatase activity in cucumber (Cucumis sativus L.) seedlings. Environmental $\begin{array}{llll}\text { and } \quad \text { Experimental } & \text { Botany, }\end{array}$ http://dx.doi.org/10.1016/j.envexpbot.2005.10.009

MISHRA, S. DUBEY, R.S. 2008. Changes in phosphate content and phosphatase activities in rice seedlings exposed to arsenite. Brazilian Journal of Plant Physiology, 20, 19-28. http://dx.doi.org/10.1590/S1677-04202008000100003 